\title{
Linking intra-tree-ring wood density variations and tracheid anatomical characteristics in Douglas fir (Pseudotsuga menziesii (Mirb.) Franco)
}

\author{
Cyrille B. K. RATHGEBER ${ }^{\mathrm{a} *}$, Valérie DeCOUX ${ }^{\mathrm{b}, \mathrm{c}}$, Jean-Michel Leban $^{\mathrm{a}}$ \\ ${ }^{a}$ Centre INRA de Nancy, UMR INRA-ENGREF 1092, Laboratoire d'Étude de la Ressource Forêt-Bois (LERFoB), Équipe de Recherche \\ Qualité des Bois, 54280 Champenoux, France \\ b Université Libre de Bruxelles, 50 av. F. Roosevelt, SAAS-CP165/55, 1050 Brussels, Belgium \\ ${ }^{\mathrm{c}}$ Current address: Ministère de la région de Bruxelles capitale, administration de l'équipement et des déplacements, direction des voiries, \\ cellule plantations, 80 rue du Progrès, 1030 Brussels, Belgium
}

(Received 19 December 2005; accepted 12 May 2006)

\begin{abstract}
In this study, a geometric approach was used in order to model the relationships between intra-tree-ring wood density variations and tracheid anatomical characteristics. One Douglas fir was studied in detail. Anatomical slides of 256 tree-rings were compared with the corresponding density profiles. Radial and tangential tracheid diameters decline from earlywood to latewood by $50 \%$ and $15 \%$, respectively. At the same time, radial and tangential cell-wall thicknesses increase by $110 \%$ and $132 \%$, respectively. Wood density exhibits an S-shape profile with a slight decrease of $10 \%$ at the beginning of a ring and an increase of $212 \%$ thereafter. Model simulations showed that wood density increase is mainly due to cell-wall thickening in tangential and radial directions as well as cell size reduction in radial direction. Simulations also showed that the knowledge of tracheid anatomical characteristics is not sufficient to fully explain wood density decrease at the beginning of earlywood.
\end{abstract}

wood density / wood anatomy / wood quality / image analysis / Douglas fir (Pseudotsuga menziesii (Mirb.) Franco)

Résumé - Relations entre les variations de densité à l'intérieur du cerne et les caractéristiques anatomiques des trachéides pour le sapin de Douglas (Pseudotsuga menziesii (Mirb.) Franco). Un modèle géométrique a été utilisé dans le but de modéliser les relations entre les variations de densité à l'intérieur du cerne et les caractéristiques anatomiques des trachéides. Un sapin de Douglas a été étudié en détail. Des images numériques de coupes anatomiques de 256 cernes ont été comparées aux profils de densité correspondants. Du bois initial au bois final, les diamètres radiaux et tangentiels des trachéides diminuent de $50 \%$ et $15 \%$ respectivement, pendant que les épaisseurs radiales et tangentielles des parois cellulaires augmentent de $110 \%$ et $132 \%$ respectivement. La densité du bois présente un profil en forme de S, avec une légère diminution de $10 \%$ au début du cerne et une augmentation de $212 \%$ ensuite. Le modèle a montré que l'augmentation de la densité est principalement due à l'épaississement des parois cellulaires dans les directions tangentielles et radiales et à la diminution du diamètre radial des cellules. Ce modèle a également montré que la connaissance des caractéristiques anatomiques des trachéides n'est pas suffisante pour expliquer complètement la diminution de densité constatée au début du bois initial.

densité du bois / anatomie du bois / qualité du bois / analyse d'image / sapin de Douglas (Pseudotsuga menziesii (Mirb.) Franco)

\section{INTRODUCTION}

Wood density is widely used as an estimator of wood quality because of its good relationships with various wood properties. For example, wood density plays a prominent role for e.g. wood strength, workability, and decay resistance and in carbon sequestration ability $[1,17,18,28,31,42]$. However, relationships between wood density and other wood properties are often indirect, making them difficult to interpret. Wood density is a measure of the amount of matter available, but does not contain any information about its cellular structure or organisation. Since wood density is a measure of the total amount of cell-wall material available per volume unit, it is related to the relative proportions of the different cell types, as well as to

\footnotetext{
* Corresponding author: cyrille.rathgeber@nancy.inra.fr
}

the dimensions of these cells and the thicknesses of the cellwalls. However, for the same wood density, differences at the cellular level may occur, causing variations in wood properties [40]. Consequently, it is important to know to what extent cell anatomical characteristics affect wood density.

Multiple regressions and similar statistical techniques are widely applied to estimate wood density from various anatomical characteristics $[5,6,19,24,25,36,41]$. The key results of these studies are that tree-ring density is highly correlated with earlywood tracheid diameter and latewood percentage. Statistical models, however, are usually restricted to species and conditions for which they were developed. Moreover, statistical model interpretation is not easy; for example, it is not really possible to single out the influence of individual variables. 
Mechanistic models, on the other hand, are rarely applied because they need specific variables that are not easy to measure. However, mechanistic models are more flexible and generally applicable to various conditions and species. Mechanistic models have been developed for softwood to assess how cell anatomical characteristics relate to wood density [35]. Wimmer [39] designed a geometric model in order to investigate potential and actual influences of cell anatomical characteristics on tree-ring density. Wimmer's study [39] showed that, for conifers, radial diameter and cell-wall thickness of latewood tracheids have the greatest influence on tree-ring density, while tracheid length and other cell characteristics, i.e. parenchyma rays and resin canals, can be neglected. A strong assumption of Wimmer's model [39] is that tracheid cross sections are of rectangular shape. Decoux et al. [8] by testing two different models of tracheid shapes for three different conifer species showed that this simplification is acceptable. On the other hand, Decoux et al. [8] also suggested calibrating the geometric model with apparent cell-wall density. The apparent cell-wall density, or packing density, which varies within a tree-ring, is far smaller than the effective cell-wall density usually reported in the literature [8].

Apart from Decoux et al. [8], all the previous studies used average earlywood and latewood cell characteristics [30] in order to explain inter-tree-ring density variations. In this study, statistical and mechanistic approaches are used to model, at a cellular level, relationships between intra-tree-ring wood density variations and tracheid cross-sectional anatomical characteristics. The objectives are (1) assessing to what extend tracheid cross-sectional anatomical characteristic evolution explains intra-tree-ring wood density change, and (2) sorting out tracheid anatomical characteristics in order of importance.

The work was carried out with Douglas fir (Pseudotsuga menziesii (Mirb.) Franco) because the wood density of this species is characterised by a strong inter- and intra-tree-ring heterogeneity [37]. Moreover, Douglas fir is of great interest in forestry as it combines strong productivity and high wood quality.

\section{MATERIALS AND METHODS}

\subsection{Tree sampling}

One 35 year old Douglas fir was felled in April 1998. Height was $24.7 \mathrm{~m}$ and the diameter at breast height (DBH) was $33 \mathrm{~cm}$. Thirteen cross-sectional disks were cut at various heights, with approximately one disk every two growth units. The studied tree came from an experimental design located in Amance Forest $\left(48.75^{\circ} \mathrm{N}, 6.35^{\circ} \mathrm{E}\right)$ near Nancy (Lorraine, north-eastern France). It was taken from a stand that reached a dominant height of $24 \mathrm{~m}$ for a mean DBH of $26.6 \mathrm{~cm}$, with a basal area of $63.3 \mathrm{~m}^{2} / \mathrm{ha}$. Only very little pruning and thinning were conducted on this stand.

For each of the 13 disks one radial strip was sawn, oriented south, and containing the pith. Each radial strip was cut into two parallel samples. The first sample was submitted to X-ray densitometry analysis, while the second sample was submitted to anatomical analysis. In total, 256 tree-rings were sampled.

\subsection{X-ray densitometry}

Wood strips were X-rayed following standard techniques [26,31, 32]. Radiographs were digitalised using a scanner. The digital images were treated using semi-automatic procedures $[26,27]$. Each tree-ring was divided in 100 segments of equal width. Density profiles were produced by averaging the values (XRD, $\mathrm{kg} / \mathrm{m}^{3}$ ) obtained from these segments.

\subsection{Anatomical slides analysis}

Samples for the anatomical analysis were cut into small blocks before being sliced with a microtome. A section thickness of $12 \mu \mathrm{m}$ was chosen because it compromise, according to Park [29] and Donaldson et al. [11], readability vs. conservation of structural identity. Sections were stained ensuring uniform colours crucial for image analysis $[7,21]$. Sections were then placed on slides and fixed with cover slips. Tree-ring images were acquired at a magnification of 300 using a digital camera mounted on an optical microscope.

The initial images (comprising 256 grey levels) were converted into binary images where black pixels correspond to matter (cell-wall of tracheids, parenchyma rays or resin canals), and white pixels correspond to voids (lumens of tracheids, parenchyma rays, resin canals and pores). On each tangential row of pixels, the number of black pixels (nbp) and the number of white pixels (nwp) were counted. The proportion of matter for an area, i.e. the cell-wall proportion (CWP), is then obtained as followed:

$$
\mathrm{CWP}=\mathrm{nbp} /(\mathrm{nwp}+\mathrm{nbp}) .
$$

CWP does take into account cell-walls from tracheids, as well as those from parenchyma rays and resin canals.

Packing density $\left(\mathrm{PKD}, \mathrm{kg} / \mathrm{m}^{3}\right)$ is used to describe the ratio between wood density and cell wall proportion $[12,22,36]$ :

$$
\mathrm{PKD}=\mathrm{XRD} / \mathrm{CWP} \text {. }
$$

Tracheids were automatically recognized on tree-ring images. Means and standard deviations of tracheid characteristics were continuously computed for a window of 200 by 200 pixels that was progressively moved by 10 pixels in radial direction. Only complete tracheids within the window were considered for measurements. As for the density analysis, each tree-ring was divided in 100 segments of equal width. Averaged values obtained from these segments were used to make continuous profiles for the following variables:

- cell, lumen and wall surfaces as well as cell and lumen perimeters (called SCell, SLum, SWall, PCell and Plum respectively);

- cell, lumen and wall dimensions, measured in the radial and tangential directions (called RCell, TCell, RLum, TLum, RWall, TWall respectively).

\subsection{Geometric model of wood density}

From these primary anatomical variables, morphometric density (MMD) was obtained by the following equation:

$$
\mathrm{MMD}_{\mathrm{a}}=\mathrm{SWall} / \mathrm{SCell} \text {. }
$$

Decoux et al. [8] showed that for conifers it is reasonable to base calculations on a rectangular tracheid shape. So, geometric model of 
wood density based on tracheid and lumen diameters can be written as:

$$
\mathrm{MMD}_{\mathrm{b}}=1-\frac{\text { RLum } \times \text { TLum }}{\text { RCell } \times \text { TCell }}
$$

Equation (4) possesses the advantage of simplicity, using moreover, very easy to measure variables. However, in order to test the sensitivity of wood density to the different components of the model, it is better to use more informative variables:

$$
\mathrm{MMD}_{\mathrm{c}}=\left[\frac{2 \cdot \mathrm{TWall}}{\mathrm{TCell}}+\frac{2 \cdot \mathrm{RWall}}{\mathrm{RCell}}-\frac{4 \cdot \mathrm{RWall} \times \mathrm{TWall}}{\mathrm{RCell} \times \mathrm{TCell}}\right] .
$$

Simple linear regressions, computed using $\mathrm{SAS}^{\circledR}$ software [33], were used in the following paragraphs to describe the results.

\subsection{Comparison of the two measurement techniques}

Differences concerning the field-of-view and the measurement accuracy must be taken into account when comparing data from the two methods. On the one hand, field-of-view of X-ray densitometry (ring width in radial direction $\times 2 \mathrm{~mm}$ in tangential direction $\times$ $2 \mathrm{~mm}$ in longitudinal direction) is wider than the one of anatomical images (ring width in radial direction $\times 1 \mathrm{~mm}$ in tangential direction $\times 12 \mu \mathrm{m}$ in longitudinal direction). On the other hand, X-ray densitometry resolution is relatively low $(25.40 \mu \mathrm{m} / \mathrm{pixel})$, while resolution of anatomical slide images is considerably higher $(0.76 \mu \mathrm{m} /$ pixel $)$ The 3 firsts and the 3 lasts segments of each tree-ring were removed from the dataset because it was possible to capture the sharp change between the end and the start of a tree-ring with image analysis of anatomical slides but not with X-ray densitometry.

Image analysis of $\mathrm{X}$-ray radiographs and anatomical slides both provided a measurement for tree-ring widths. This allows comparing directly the accuracy of the two methods and assesses data quality. There is a close relationship between tree-ring widths measured by X-ray densitometry (TRW_XR) and tree-ring widths measured by image analysis on anatomical slides (TRW_AS). Simple linear regression explain $99 \%$ of the variance and shows that there is no systematic bias between the two types of measurements (TRW_XR = $0.02+0.97$. TRW_AS). With the exception of height, all measurement pairs were located within the $95 \%$ confidence interval. Dubious values come from tree-rings close to the pith, or exhibiting much curved limits or accidents. The height outliers were removed from the dataset. The difference between the two measurement techniques was greater for rings close to the pith because it was more difficult to accurately delimit tree-ring boundaries. The innermost tree-ring for each growth unit was also removed from the dataset because X-ray densitometry could not accurately distinct the pith and the first ring.

\section{RESULTS}

\subsection{Tracheid characteristics and wood density profiles}

Cell diameters generally declined from earlywood to latewood. Reduction of radial diameters started right from the beginning of a ring, while it only became sensible after $1 / 3$ of a ring for tangential diameters (Fig. 1A). On average, radial cell diameters went down to half their size (i.e. from $45 \mu \mathrm{m}$ to $24 \mu \mathrm{m}$ ), while tangential cell diameters lost only $15 \%$ of their size (i.e. from $38 \mu \mathrm{m}$ to $32 \mu \mathrm{m}$ ). Because cell size reduction was more expressed in the radial direction, the ratio between tangential and radial diameters increased from 0.85 to 1.43 . These changes led to a decline in cell perimeters by $36 \%$ on average, i.e. from $144 \mu \mathrm{m}$ to $92 \mu \mathrm{m}$ (not shown); as well as a decline in cell surfaces by $60 \%$, i.e. from $1260 \mu \mathrm{m}^{2}$ to $500 \mu \mathrm{m}^{2}$ (Fig. 1D).

Lumen diameter reduction, from the beginning of a ring to its end, was even greater than the one seen for cell diameter (Fig. 1B). Radial lumen diameters went down by $74 \%$ on average, (i.e. from $39 \mu \mathrm{m}$ to $10 \mu \mathrm{m}$ ), while tangential lumen diameters went down by $52 \%$, i.e. from $31 \mu \mathrm{m}$ to $15 \mu \mathrm{m}$. Because lumen diameter reduction was more expressed in the radial direction, the ratio between tangential and radial diameters increased from 0.80 to 1.68 . These changes led to a decline in lumen perimeters by $67 \%$, i.e. from $120 \mu \mathrm{m}$ to $40 \mu \mathrm{m}$ (not shown). Further a huge decrease by $88 \%$ was seen for lumen surfaces, i.e. from $940 \mu \mathrm{m}^{2}$ to $110 \mu \mathrm{m}^{2}$ (Fig. 1D). Because size reduction affected lumen more than entire cell, the ratio between lumen and cell surfaces decreased from 0.70 to 0.20 .

From the initial tracheids to the terminal ones, cell-wall thicknesses showed an overall increase (Fig. 1C). In the radial direction, cell-wall thicknesses increased by $110 \%$, i.e. from $3.2 \mu \mathrm{m}$ to $6.8 \mu \mathrm{m}$. In the tangential direction, cell-wall thickness increased by $132 \%$, i.e. from $3.8 \mu \mathrm{m}$ to $8.8 \mu \mathrm{m}$. However, thinner cell-walls were not found directly at the very beginning of a tree-ring but around a relative position of 0.08 . In tangential direction maximal cell-wall thicknesses were found at the very end of a ring, however in radial direction they were found at a relative position of 0.92 . The ratio between tangential and radial thicknesses decreased gradually within the first $60 \%$ of a ring, but increased rapidly during the final $40 \%$. So, radial thicknesses increased faster than tangential ones in the first half of a tree-ring, while tangential thicknesses increased faster in the second half of the tree-ring. Changes in cell-wall thickness together with changes in cell and lumen diameters led to an increase of cell-wall surfaces by $33 \%$, i.e. from $330 \mu \mathrm{m}^{2}$ to $440 \mu \mathrm{m}^{2}$ (Fig. 1D). Cell-wall surfaces accentuated what was observed for cell-wall thicknesses: a dip at the relative position 0.2 of the profile, and a top at the relative position 0.85 of the profile.

From the beginning of a tree-ring to its end, wood density (XRD) exhibited an S-shape profile with a slight decrease occurring during the first $20 \%$ of a ring (Fig. 2A). As a consequence, XRD decreased by $10 \%$, i.e. from 313 to $283 \mathrm{~kg} / \mathrm{m}^{3}$, before increasing by $212 \%$, reaching $882 \mathrm{~kg} / \mathrm{m}^{3}$ at the end of a tree-ring. The cell-wall proportion (CWP) and XRD profiles were parallel, but the dip at the beginning of the profile is less accentuated for CWP. On average, CWP decreased by 5\%, i.e. from 0.312 to 0.295 , before increasing by $170 \%$, reaching 0.796 at the end of a tree-ring.

\subsection{Relationships between wood density and tracheid characteristics}

There was a very good correlation between XRD and CWP. The simple linear regression model explained $93 \%$ of the total variance $(R=0.96 ; p<0.001)$. The conversion factor of 

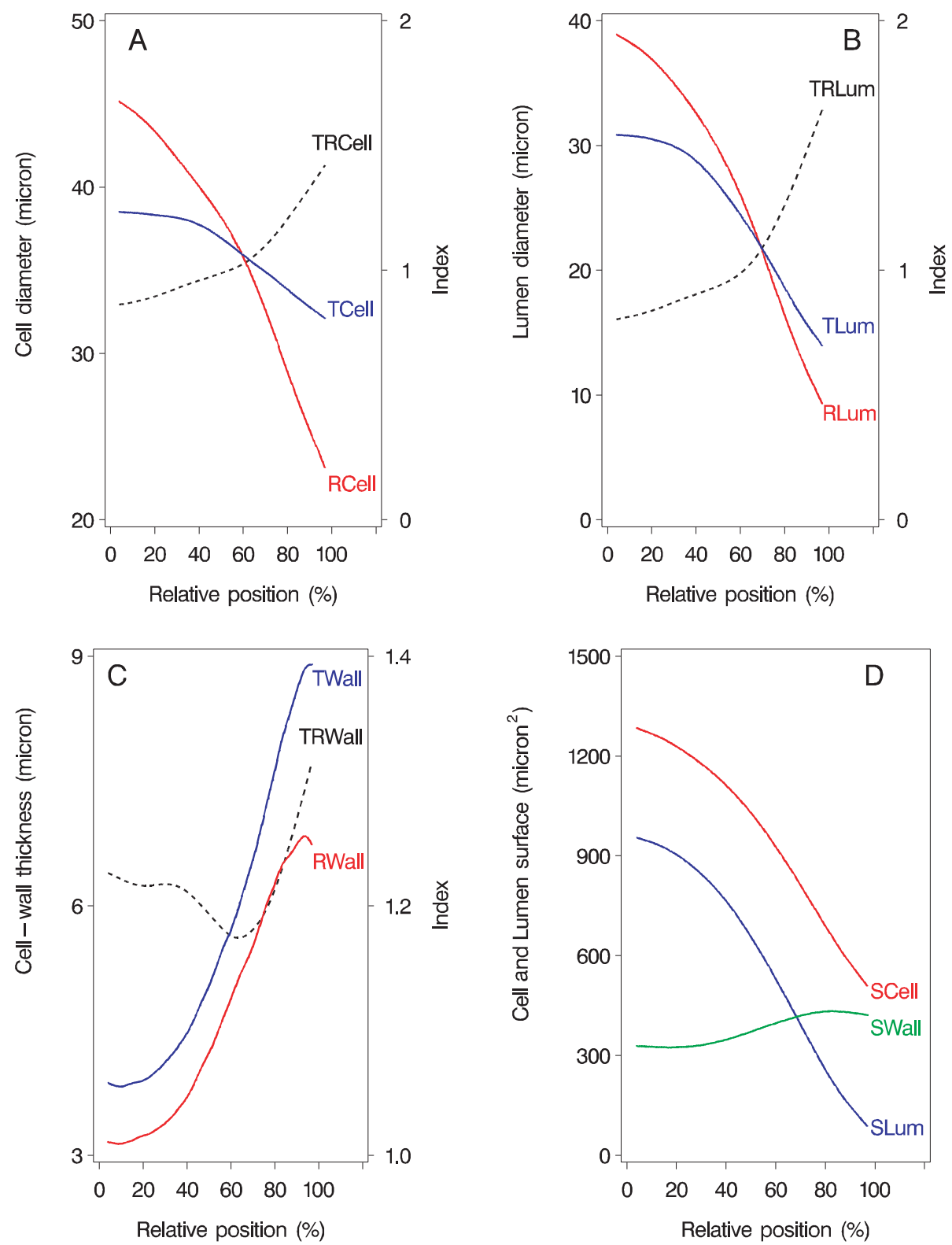

Figure 1. Tracheid characteristic profiles. A. Radial and tangential cell diameters (RCell and TCell respectively) as well as the ratio TCell / RCell (TRCell). B. Radial and tangential lumen diameters (RLum and TLum respectively) as well as the ratio TLum / RLum (TRLum). C. Radial and tangential cell-wall thickness (RWall and TWall respectively) as well as the ratio TWall / RWall (TRWall). D. Cell, lumen and cell-wall surfaces (SCell, SLum and SWall respectively). Curves were smoothed using a spline function [33].

CWP to XRD (with the intercept set to 0) was 1060. However, the relationship between XRD and CWP was not perfectly linear. For the highest densities, XRD increased faster than CWP, and for the lowest densities, XRD decreased faster than CWP. Packing density (PKD) decreased by $4 \%$ within the first $20 \%$ of a ring (i.e. from $1010 \mathrm{~kg} / \mathrm{m}^{3}$ to $970 \mathrm{~kg} / \mathrm{m}^{3}$ ) and increased by $13 \%$ afterwards, reaching $1100 \mathrm{~kg} / \mathrm{m}^{3}$ at the end of the ring (Fig. 2B).

Both XRD and CWP correlated significantly with almost all studied anatomical variables (Tab. I); the best correlations were obtained with RLum and PLum $(R>0.90)$, further RWall, TWall, Slum and TLum $(R>0.80)$. However, the relationships between the anatomical variables and XRD or CWP turned out to be nonlinear, which makes it difficult to predict wood density with one of these primary variables. By contrast, morphometric density exhibited a quasi-linear relation- ship with CWP and XRD. Very good correlation were found between CWP and $\mathrm{MMD}_{\mathrm{a}}(R=0.97 ; p<0.001)$; the simple linear regression model explains $94 \%$ of the total variance. The conversion factor of $\mathrm{MMD}_{\mathrm{a}}$ to CWP (with the intercept set to 0 ) was 1 . The ratio between CWP and $\mathrm{MMD}_{\mathrm{a}}$ decreased within the first half of a tree-ring; then it reached a plateau, and remained constant in the second half of the tree-ring (Fig. 2B).

Correlations were high between the different morphometric densities $\left(\mathrm{MMD}_{\mathrm{a}}, \mathrm{MMD}_{\mathrm{b}}\right.$ and $\left.\mathrm{MMD}_{\mathrm{c}}\right)$. Simple linear regression models explained over $99 \%$ of the total variance. The results confirmed that the rectangular tracheid shape was the right choice. XRD and $\mathrm{MMD}_{\mathrm{c}}$ were also highly correlated. Simple linear regression model explained $89 \%$ of the total variance $(R=0.94 ; p<0.001)$; the conversion factor of $\mathrm{MMD}_{\mathrm{c}}$ in XRD (with intercept set to 0) is 985.94 . So, it is 


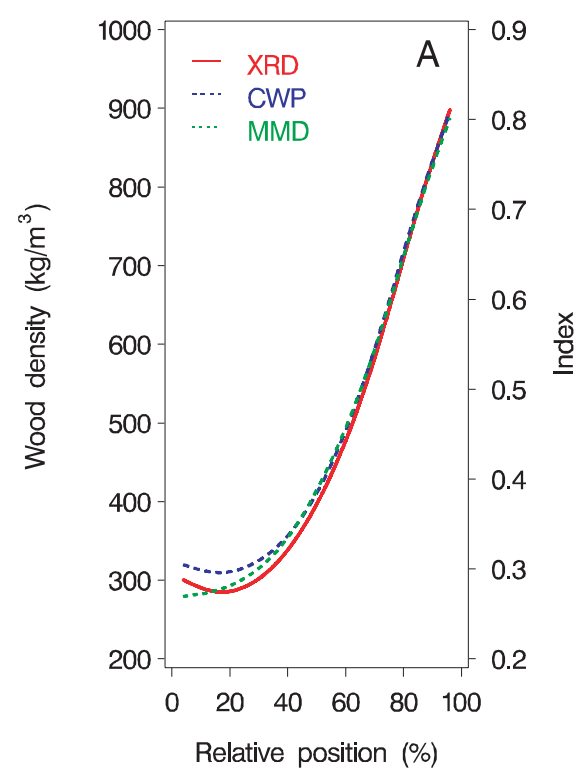

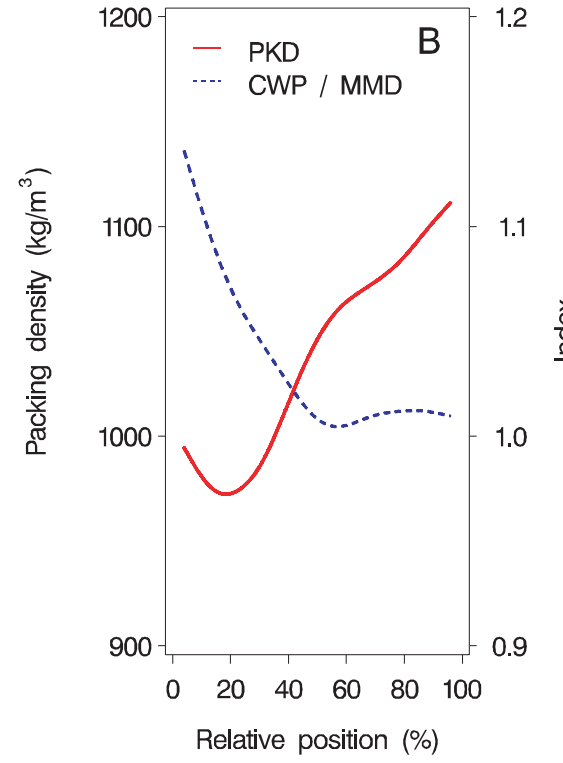

Figure 2. Comparison between wood density and cell wall proportion. A. Wood density (XRD), cell-wall proportion (CWP) and morphometric density (MMD, Eq. (5)) profiles along an average tree-ring. B. Packing density (PKD) and CWP / MMD profiles along an average tree-ring. Curves were smoothed using a spline function [33].
Table I. Correlations between wood density and tracheid characteristics. Pearson correlation coefficients computed between wood density (XRD) and cell-wall proportion (CWP) on the one hand; and anatomical variables on the other hand. Stars indicate significant correlation $(p<0.01, n=96)$.

\begin{tabular}{lccc}
\hline Variable & Code & XRD & CWP \\
\hline Morphometric density (Eq. (5)) & MMDc & $0.94^{*}$ & $0.97^{*}$ \\
Lumen radial diameter & RLum & $-0.89^{*}$ & $-0.92^{*}$ \\
Lumen perimeter & PLum & $-0.88^{*}$ & $-0.91^{*}$ \\
Cell-wall radial diameter & RWall & $0.87^{*}$ & $0.88^{*}$ \\
Cell-wall tangential diameter & TWall & $0.86^{*}$ & $0.88^{*}$ \\
Lumen surface & SLum & $-0.83^{*}$ & $-0.86^{*}$ \\
Cell radial diameter & RCell & $-0.82^{*}$ & $-0.84^{*}$ \\
Lumen tangential diameter & TLum & $-0.81^{*}$ & $-0.84^{*}$ \\
Cell perimeter & PCell & $-0.73^{*}$ & $-0.76^{*}$ \\
Cell surface & SCell & $-0.72^{*}$ & $-0.75^{*}$ \\
Cell tangential diameter & TCell & $-0.42^{*}$ & $-0.46^{*}$ \\
Cell-wall perimeter & SWall & $0.38^{*}$ & $0.36^{*}$ \\
\hline
\end{tabular}

feasible to compute intra-ring density variations from tracheid basic characteristics.

\subsection{Exploration of the geometric wood density model}

The geometric model allows analysing the contribution of the various tracheid characteristics independently, in order to evaluate their relative influences on wood density. For the first set of simulations, all the variables in the model were fixed to values they take at the beginning of a ring, with exception of the variable of interest, which altered along the ring (Fig. 3A). Under these presumptions, tracheid size reduction led to a wood density increase by $42 \%$, while cell-wall thickening led to a $102 \%$ increase. When anatomical variables were examined independently, radial and tangential tracheid diameters, radial and tangential thicknesses of cell-wall and packing density led to an increase in wood density by $34,12,43,74$ and $17 \%$, respectively.

For the second set of simulations, all the variables of the model altered, with exception of the variable of interest, which was fixed to its initial value at the beginning of a ring (Fig. 3B). When radial and tangential diameters were kept constant, wood density loosed 22\%; and when radial and tangential thicknesses were kept constant, wood density loosed $45 \%$. When anatomical variables were examined independently radial and tangential diameters, radial and tangential thicknesses and packing density were responsible for a wood density loss of $15,4,17,16$ and $12 \%$, respectively.

\section{DISCUSSION}

\subsection{Comparison between density data and anatomical data}

In this study, anatomical data acquired from microscopic thin sections (12 $\mu \mathrm{m}$ thick) were compared with their corresponding density obtained from wood strips ( $2 \mathrm{~mm}$ thick). It was assumed that anatomical measurements made on thin sections were representative for thick wood strips. This assumption seems to be realistic considering component characteristics of conifer wood. Tracheids are long tubular cells (between 3.5 and $5.0 \mathrm{~mm}$ for Douglas fir) oriented in the longitudinal direction. In longitudinal direction, tracheid section and cellwall thickness are quasi-constant, only tracheid short tips are slightly thin down $[15,23]$. Resin canals are very long tubular cells oriented in the longitudinal direction as well. Their morphology is also quasi-constant all along their length [3]. Parenchyma rays, on the contrary, are composed for Douglas fir by lines of 8 to 15 round cells stretched out in the radial direction [34]. Cell-wall proportion variability associated to 


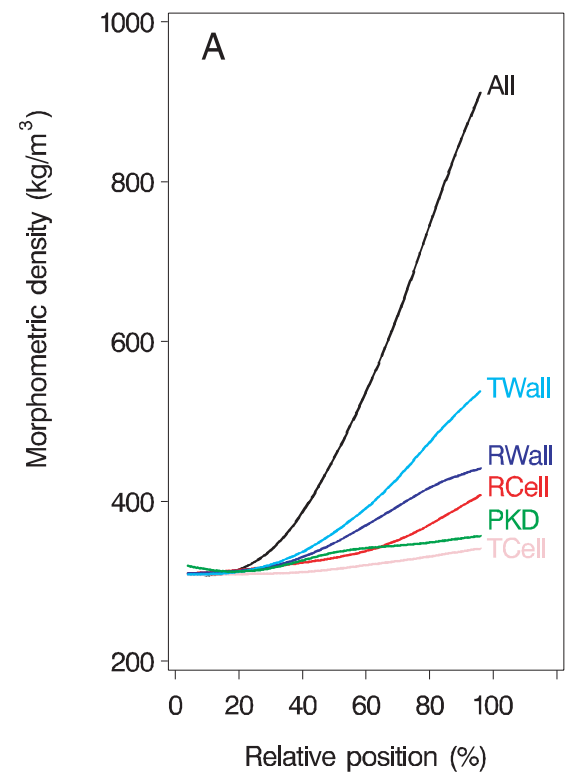

parenchyma ray characteristics in a longitudinal direction is not consistent with the assumption mentioned above. However, parenchyma rays are rare in Douglas fir [34].

When comparing wood density, cell-wall proportion and anatomical characteristics, it must be kept in mind that wood density and cell-wall proportion were measured on the whole sample, while anatomical characteristics were measured on tracheids only. Therefore, it was assumed in this study that wood is solely composed of tracheids. In fact, in conifer species, tracheids represent 90 to $95 \%$ of the total number of cells, while parenchyma rays only represent around $6 \%$ and resin canals around $1 \%[2,15,28]$.

\subsection{Tracheid morphological changes}

From the beginning of a tree-ring to its end, cell and lumen diameters decrease while cell-wall thicknesses increase; these anatomical modifications lead to an increase of cell wall proportion $[4,10,13,37]$. Cell and lumen diameter changes along a tree-ring are greater in the radial direction than in the tangential one [14]. Cell and lumen tangential diameter reduction mainly occurs in latewood because anticlinal divisions take place more frequently at the end of the growing season $[14,19]$. By contrast, cell-walls are thicker in tangential direction than in radial one [10], and cell-wall thickening is greater in the tangential direction than in the radial one. In summary, cell size diminution principally takes place in the radial direction; while cell-wall thickness augmentation takes place in the tangential direction but also in the radial one. Variations of cell-wall thickness are larger than those of cell size [16,20].

It was observed in this study that cell-wall surface and also cell-wall thickness slightly decrease at the beginning and at the end of a tree-ring. Cell-wall thickness reduction at the end of a tree-ring is already mentioned by Wang et al. [38] on black spruce (Picea mariana Mill.).

\subsection{Relationship between tracheid characteristics and wood density}

Lumen perimeter and lumen radial diameter are the anatomical variables which best correlated with wood density. From an image analysis point of view, an anatomical image of a tree-ring can be summarised as a black square of constant area where lumens are represented by white dots of various diameters. From this schematic view lumen size can be considered as a direct estimation of void area and density. So, lumen characteristics deserve to be more often reported in future anatomical studies.

Geometric model simulations show that for Douglas fir wood density augmentation along a ring is caused by (by order of importance): (1) cell-wall thickening in tangential direction; (2) cell-wall thickening in radial direction; (3) cell size diminution in the radial direction; (4) packing density augmentation; and (5) cell size diminution in the tangential direction. Despites the fact that variables, resolution and species were not the same, our results came close to those presented by Wimmer [39]. Application of Wimmer's model on Scots pines from Austria shows that potentially the most important factors influencing wood density are tracheid radial and tangential cellwall thicknesses and tracheid radial diameter, while tracheid tangential diameter and tracheid length have almost no effect. However, when taking into account natural variability, tracheid radial diameter becomes the most important factor, while tracheid tangential cell-wall thickness ranks second.

In this study, a decrease of wood density was clearly observed at the beginning of a ring. To a lesser extend, a decrease of cell-wall proportion was also observed. On the other hand, no decrease at all was observed for morphometric density (if packing density is not taken into account) despite the decrease of cell-wall thickness. In fact, cell-wall thickness diminution does not explain density decrease because it is compensated by cell size reduction. So, cell-wall proportion diminution should 
also be attributed to factors not taken into account in the geometric model, like augmentation of inter-cellular spaces for example. Moreover, cell-wall proportion diminution does not fully explain wood density diminution. Factors like cell-wall composition or tracheid length could be responsible for this difference. Deleuze and Houiller's process-based model of xylem growth [9] simulates a diminution of wood density at the beginning of a ring, and explains it by a temporary shortage in substrate for cell-wall construction.

\section{CONCLUSION}

Wood density increase along a ring was mainly due to tracheid anatomical changes: i.e. tracheid cell-wall thickening and tracheid radial diameter diminution. Packing density augmentation and tracheid tangential diameter diminution only play minor roles. However, to fully understand density variations along a ring, it is necessary to explain packing density variations and in particular reasons why wood density decreases at the beginning of a ring. To do that, anatomical observations of tracheid cell-wall need to be coupled with chemical measurements.

This paper focussed on the relationship between wood density and tracheid characteristics along a tree-ring, i.e. on intratree-ring variations. However, it is also interesting from these data to investigate how wood density and tracheid characteristics vary from one tree-ring to another (inter-tree-ring variations) and how internal and external factors are related to these variations. A following paper will focus on these points with a particular emphasis on climate influences.

Acknowledgements: We would like to thank Pierre Gelhaye for micro-densitometry measurements. We are also grateful to Joëlle Kivits, Fleur Longueteaud and two anonymous reviewers for improving the manuscript.

\section{REFERENCES}

[1] Barbosa R.I., Fearnside P.M., Wood density of trees in open savannas of the Brazilian Amazon, Forest. Ecol. Manage. 199 (2004) $115-123$.

[2] Brown H.P., Panshin A.J., Forsaith C.C., Textbook of wood technology, McGraw-Hill, New York, 1949.

[3] Core H.A., Côté W.A., Day A.C., Wood structure and identification, Syracuse University Press, New York, 1979.

[4] De Kort I., Loeffen V., Baas P., Ring width, density and wood anatomy of Douglas-fir with different crown vitality, IAWA B. 12 (1991) 453-465.

[5] De Kort I., Relationships between sapwood amount, latewood percentage, moisture-content and crown vitality of Douglas-fir, Pseudotsuga-Menziesii, IAWA J. 14 (1993) 413-427.

[6] De Kort I., Wood production and latewood percentage of Douglasfir from different stands and vitality classes, Can. J. Forest. Res. 23 (1993) 1480-1486.

[7] Decoux V., Contribution à l'interprétation anatomique des microvariations de la densité du bois de Douglas, Ph.D. thesis, Université Libre de Bruxelles, 2003.
[8] Decoux V., Varcin E., Leban J.M., Relationships between the intraring wood density assessed by X-ray densitometry and optical anatomical measurements in conifers. Consequences for the cell wall apparent density determination, Ann. For. Sci. 61 (2004) 251262

[9] Deleuze C., Houllier F., A simple process-based xylem growth model for describing wood microdensitometric profiles, J. Theor. Biol. 193 (1998) 99-113.

[10] Diaz-Vaz J.E., Echols R., Knigge W., Vergleichende Untersuchung der Schwankungen von Tracheidendimensionen und röntgenoptisch ermittelter Rohdichte innerhalb des Jahrrings, Forst-Wiss. Centralbl. 94 (1975) 161-175.

[11] Donaldson L.A., Lausberg M.J.F., Comparison of conventional transmitted light and confocal microscopy for measuring wood cell dimensions by image analysis, IAWA J. 19 (1998) 321-336.

[12] Elliott G.K., Brook S.E.G., Microphotometric technique for growth-ring analysis, J. Inst. Wood Sci. 18 (1967) 24-43.

[13] Erickson H.D., Harrison A.T., Douglas-fir wood quality studies, part I: effects of age and stimulated growth on wood density and anatomy, Wood Sci. Technol. 8 (1974) 207-226.

[14] Fengel D., Stoll M., On the variation of the cell cross area, the thickness of the cell wall and of the wall layers of sprucewood tracheids within an annual ring, Holzforschung 27 (1973) 1-7.

[15] Fengel D., Wegener G., Wood: chemistry, ultrastructure, reactions, Walter de Gruyter, Berlin, 1989.

[16] Ferrand J.C., Réflexion sur la densité du bois, $1^{\text {re }}$ partie : définition de la densité du bois, Holzforschung 36 (1982) 99-105.

[17] Gilmore A.R., Metcalf G.E., Boggess W.R., Specific gravity of shortleaf pine and loblolly pine in southern Illinois, J. For. 59 (1959) 894-896.

[18] Guilley E., Herve J.C., Nepveu G., The influence of site quality, silviculture and region on wood density mixed model in Quercus petraea Liebl., For. Ecol. Manage. 189 (2004) 111-121.

[19] Hannrup B., Danell O., Ekberg I., Moell M., Relationships between wood density and tracheid dimensions in Pinus sylvestris L., Wood Fiber Sci. 33 (2001) 173-181.

[20] Heger L., Parker M.L., Kennedy R.W., X-ray densitometry: a technique and an example of application, Wood Sci. 7 (1974) 140-148.

[21] Ilic J., Hillis W.E., Video image processor for wood anatomical quantification, Holzforschung 37 (1983) 47-50.

[22] Jayme G., Krause T., Über die Packungsdichte der Zellwände in Laubhölzern, Holz als Roh- Werkst. 21 (1963) 14-19.

[23] Kibblewhite R.P., Bailey D.G., Measurement of fibre cross-section dimensions using image analysis, APPITA 41 (1988) 297-303.

[24] Leclerq A., Relationships between beechwood anatomy and its physico-mechanical properties, IAWA B. 1 (1980) 65-71.

[25] Lindström H., Fiber length, tracheid diameter, and latewood percentage in Norway spruce: Development from pith outwards, Wood Fiber Sci. 29 (1997) 21-34

[26] Mothe F., Duchanois G., Zannier B., Leban J.M., Microdensitometric analysis of wood samples: data computation method used at Inra-ERQB (CERD program), Ann. Sci. For 55 (1998) 301-313.

[27] Mothe F., Sciama D., Leban J.M., Nepveu G., Localization of the earlywood-latewood transition in oak rings using microdensitometric analysis, Ann. Sci. For. 55 (1998) 437-449.

[28] Panshin A.J., De Zeeuw C., Textbook of wood technology, McGraw-Hill, New York, 1980.

[29] Park W.K., Development of the microtechniques for the image analysis of tree rings, J. Agr. Sci. 9 (1991) 16-21. 
[30] Park Y. I., Dallaire G., Morin H., A method for multiple intra-ring demarcation of coniferous trees, Ann. For. Sci. 63 (2006) 9-14.

[31] Polge H., Établissement des courbes de variation de la densité du bois par exploration densitométrique de radiographies d'échantillons prélevés à la tarière sur des arbres vivants Applications dans les domaines technologique et physiologique, Ann. Sci. For. 23 (1966) 1-215.

[32] Polge H., Fifteen years of wood radiation densitometry, Wood Sci. Technol. 12 (1978) 187-196.

[33] SAS Institute Inc., SAS OnlineDoc ${ }^{\circledR}$, Version 8, Cary, NC, 1999.

[34] Schweingruber F.H., Microscopic Wood Anatomy, Swiss Federal Institute for Forest, Snow and Landscape Research, 1990.

[35] Smith D.M., Rapid measurement of tracheid cross-sectional dimensions of conifers, For. Prod. J. 15 (1965) 325-334.

[36] Tsoumis G., Microscopic measurement of the amount of cell wall substance in wood and its relationship to specific gravity, TAPPI J. 47 (1964) 675-677.
[37] Vonnet G., Perrin J.R., Ferrand J.-C., Réflexions sur la Densité du Bois. $4^{\mathrm{e}}$ partie: densité et hétérogénéité du bois de Douglas, Holzforschung 39 (1985) 273-279.

[38] Wang L., Payette S., Begin Y., Relationships between anatomical and densitometric characteristics of black spruce and summer temperature at tree line in northern Quebec, Can. J. For. Res. 32 (2002) 477-486.

[39] Wimmer R., Intraannual cellular characteristics and their implications for modeling softwood density, Wood Fiber Sci. 27 (1995) 413-420.

[40] Zhang S.Y., Zhong Y., Structure-property relationship of wood in East-Liaoning oak, Wood Sci. Technol. 26 (1992) 139-149.

[41] Zhang S.Y., Eyeno R., Nepveu G., Mothe F., Dhôte J.-F., Modelling wood density in European oak (Quercus petraea and Quercus robur) and simulating the sivicultural influence, Can. J. For. Res. 23 (1993) 2587-2593.

[42] Zobel B.J., Van Buijtenen J.P., Wood variations - Its causes and control, Springer-Verlag, Berlin, 1989. 